\title{
RADULAR ANOMALY IN Hemifusus pugilinus (BORN): AN OBSERVATION WITH SEM
}

\section{ANOMALIA RADULAR EN Hemifusus pugilinus (BORN): UNA OBSERVACION CON MEB}

\author{
S. Anandakumar* \\ K. Ayyakkannu \\ CAS in Marine Biology \\ Portonovo 608 502, India \\ - Present Address: Department of Zoology \\ VHNSN College \\ Virudhunagar 626001 , India
}

\begin{abstract}
Anandakumar, S. and Ayyakkannu, K. (1990). Radular anomaly in Hemifusus pugilinus (Born): an observation with SEM. Anomalía radular en Hemifusus pugilinus (Born): una observación con MEB. Ciencias Marinas, 16(2): 47-52.
\end{abstract}

\begin{abstract}
Radular anomaly involving the occasional spine on the central tooth of the radula of an adult individual of $H$. pugilinus has been recorded. The remainder of the radula was normal. The anomaly may not have interfered much with the feeding habit. The anomaly might have resulted from a mutation rather than from physical or biological means.
\end{abstract}

\section{RESUMEN}

Se ha registrado una anomalía radular concerniendo una espina ocasional en el diente central de la rádula de un individuo adulto de $H$. pugilinus. El resto de la rádula era normal. La anomalía podría no haber interferido mucho con el hábito alimenticio. La anomalía podría haber resultado más bien de una mutación que por medios físicos o biológicos.

\section{INTRODUCTION}

The species Hemifusus pugilinus is not a well described one. Satyamurthy (1960) outlined the external characters of shell and operculum and explained the pallial complex. The population structure and sexual dimorphism, biochemical studies and the habitat web centered on $I I$. pugilinus were published recently (Anandakumar, 1986; Anandakumar et al., 1986a,b; Anandakumar et al., 1988).

In research on the proboscis of the carrion feeding marine snail $H$. pugilinus, many radulae were observed under Scanning Electron Microscope (SEM) and the anomaly

\section{INTRODUCCION}

La especie Hemifusus pugilinus no ha sido bien descrita. Satyamurthy $(1960)$ delineó las características externas de la concha y el opérculo y explicó el complejo palial. Recientemente se han publicado estudios sobre la estructura de población y dimorfismo sexual, estudios bioquímicos y del habitat de $H$. pugilinus (Anandakumar, 1986; Anandakumar et al., 1986a,b; Anandakumar et al., 1988).

En la investigación sobre la probóscide del caracol marino $H$. pugilinus, que se alimenta de carroña, se observaron muchas 
was observed in only one individual. It is worth mentioning in view of the rarity of radular anomalies in gastropods and also as the radula is very important in the indentification and classification of gastropods.

\section{MATERIALS AND METHODS}

The adult individual of $H$. pugilinus in which the radular anomaly has been reported, was collected along with other marine snails of the Portonovo coast with the trawl net between 3 and 13 fathom lines. Prior to dissection, the snails were maintained for 10-24 days in moderate aquaculture tanks well equipped with continuous flow of sea water. The animals were fed with freshly collected fishes and pieces of crabs. The radula was dissected out in seawater under a binocular microscope. The radula was then boiled in strong alkaline solution up to $76-90 \% \mathrm{C}$ to remove the radular sac and muscles that were found adhered to the radula. Then the radula was dehydrated by passing through a series $30 \%, 50 \%, 70 \%$ and $90 \%$ alcohol. It was then evaporated at low temperature $\left(4^{\circ} \mathrm{C}\right)$. The dehydrated radula was mounted on a glass cover slip at its posterior and anterior ends with Duco cement. After the cement had hardened, the radula on the cover slip was placed inside the vacuum evaporator and coated with gold vapour so as to make the outer contour distinct. It was then observed with SEM and the photographs were taken at a voltage of $10-12 \mathrm{Kv}$ with various adjustments of the SEM. The SEM used in the present investigation was S-180 Stereoscan installed at the Indian Institute of Technology, Madras.

\section{RESULTS AND DISCUSSION}

In the normal adults of $H$. pugilinus the shell height ranges from $51.5 \mathrm{~mm}$ to $106.4 \mathrm{~mm}$ and the radula measures about $0.7 \mathrm{~cm}$ to 1.5 $\mathrm{cm}$ in length and $0.1 \mathrm{~cm}$ to $0.2 \mathrm{~cm}$ in width (Anandakumar, 1986). The morphometry of the animal that showed radular anomaly was $89.2 \mathrm{~mm}$ in length, $51.5 \mathrm{~mm}$ in width, $84.000 \mathrm{~g}$ in total weight, $52.876 \mathrm{~g}$ in shell weight and $16.839 \mathrm{~g}$ in animal wet weight. It showed no external anomalies. It also prejed actively like other individuals. rádulas con un Microscopio Electrónico de Barrido (MEB) y sólo se observó la anomalía en un individuo. Vale la pena mencionarlo en vista de la rareza de anomalías radulares en gastrópodos $\mathrm{y}$, también, porque la rádula es muy importante en la identificación y clasificación de gastrópodos.

\section{MATERIALES Y METODOS}

El especimen adulto de $H$. pugilinus en el cual se reportó la anomalía radular, se colectó junto con otros caracoles marinos de la costa de Portonovo con arrastres de red entre las 3 y 13 brazas. Antes de la desecación, los caracoles se mantuvieron por 10-24 días en tanques moderados de acuicultura con un sistema de flujo continuo de agua de mar. Los animales fueron alimentados con peces recién colectados y pedazos de cangrejo. Se disectó la rádula en agua de mar bajo un microscopio binocular. Luego se hirvió la rádula en una fuerte solución alcalina hasta $76-90^{\circ} \mathrm{C}$ para quitar el saco radular y los músculos adheridos a la rádula. Luego se deshidrató la rádula pasándola por una serie de $30 \%, 50 \%, 70 \%$ y 90\% de alcohol. Luego se evaporó a baja temperatura $\left(4^{\circ} \mathrm{C}\right)$. Se montó la rádula deshidratada sobre un portaobjetos de vidrio, pegando sólo sus extremos con cemento Duco. Después de endurecerse el cemento, se metió la rádula sobre el portaobjetos dentro de un evaporador de vacío y se cubrió con una capa de vapor de oro para hacer más claro el contorno externo. Luego se observó con el MEB y se tomaron fotografias a un voltaje de 10-12 Kv con varios ajustes del MEB. El MEB utilizado en este estudio fue un Stereoscan S-180 instalado en el Indian Institute of Technology, en Madrás.

\section{RESULTADOS Y DISCUSION}

En los adultos normales de $H$. pugilinus. la altura de la concha es de $51.5 \mathrm{~mm}$ a 106.4 $\mathrm{mm}$ y la rádula mide alrededor de $0.7 \mathrm{~cm}$ a $1.5 \mathrm{~cm}$ de largo y $0.1 \mathrm{~cm}$ a $0.2 \mathrm{~cm}$ de ancho (Anandakumar, 1986). La morfometría del animal que mostró anomalía radular fue de $89.2 \mathrm{~mm}$ de largo, $51.5 \mathrm{~mm}$ de ancho, $84.000 \mathrm{~g}$ de peso total, $52.876 \mathrm{~g}$ de peso de concha $\mathrm{y}$ $16.839 \mathrm{~g}$ de peso húmedo del animal. No mostró anomalías externas. También se alimentó activamente como otros individuos. 
The normal entire radula contains about 56-100 transverse rows of teeth. Each row is composed of one central or rachidian tooth, which is tricuspid and the cusps are sharp and pointed. The median cusp is shorter than the lateral cusps (Fig.1), and two laterals which are arranged one on either side of the rachidian tooth are bicuspid. The inner cusp adjacent to the rachidian tooth is shorter than the outer cusp (Fig. 2). Both rachidian and lateral teeth arise from the basal plate attached to the radular membrane. Thus the pattern of radular structure is rachiglossate type with the radular formula $1+R+1$.

The radula in which the anomaly has been recorded was $1.1 \mathrm{~cm}$ in length and 0.18 $\mathrm{cm}$ in width, characteristics of radula of a snail $89.2 \mathrm{~mm}$ in height. The anomaly is supposed to be the presence of sharp spine (Fig. 3) in the median cusp of the tricuspid rachidian teeth throughout the entire radula which is not found in normal radula. All other morphological features of the radula, including lateral and intermediate grooves, lie within the boundry of physical variation characteristics of radulae in the species $H$. pugilinus.

The actual mechanism of feeding by scraping and boring their prey by the species $H$. pugilinus is mainly aided by the action of rachidian cusps especially the prominant central one synohronously along with the lateral teeth (Carriker and Van Zandf, 1972). One sharp spine on each median cusp of the rachidian tooth of the radula of this species has been recorded as an anomaly. They may probably aid in penetration during feeding and increase the efficiency of feeding. As per the recorded morphometry, the snail has grown to a normal size and shows no external anomalies.

The anomaly may have resulted from a) mutation, b) from a malfunctioning of odontoblasts which are responsible for the secretion of the radula. The highly specific nature of the anomaly suggests that it might have arisen as a mutation. The anomaly did not show any retardation in growth of the animal that possessed it. Moreover, the behavioural pattern in feeding of the animal also confirmed this fact. Thus, the anomaly may be an advantageous one to its possessor in the competition for food.
La rádula entera normal contiene alrededor de 56-100 filas transversas de dientes. Cada fila se compone de un diente central o raquídeo, que es tricúspide, y las cúspides son afiladas y puntiagudas. La cúspide del medio es más corta que las cúspides laterales (Fig. 1), y dos laterales que están una a cada lado del diente raquídeo son bicúspide. La cúspide interior adyacente al diente raquídeo es más corta que la cúspide exterior (Fig. 2). Tanto los dientes raquídeos como los laterales salen de la placa basal unida a la membrana radular. Por tanto, el patrón de la estructura radular es de tipo raquioglosa con fórmula radular $1+R+1$.

La rádula en la cual se registró la anomalía era de $1.1 \mathrm{~cm}$ de largo y $0.18 \mathrm{~cm}$ de ancho, características de la rádula de un caracol de $89.2 \mathrm{~mm}$ de alto. Se supone que la anomalia es la presencia de una espina puntiaguda (fig. 3) en la cúspide del medio de los dientes tricúspides raquídeos a lo largo de toda la rádula, que normalmente no se encuentra en rádulas normales. Todas las otras características morfológicas de la rádula, incluyendo los surcos laterales e intermedios, caen dentro de los límites de las características de variación física de rádulas en la especie $H$. pugilinus.

El propio mecanismo de alimentación de la especie $H$. pugilinus, consistente en raspar y perforar su presa, se realiza principalmente con ayuda de la acción de las cúspides raquídeas, especialmente la prominente central, de manera síncrona con los dientes laterales (Carriker y Van Zandf, 1972). Una espina puntiaguda en cada cúspide media del diente raquídeo de la rádula de esta especie ha sido registrada como anomalía. Probablemente ayuden en la penetración durante la alimentación y a aumentar la eficiencia alimenticia. Según la morfometrfa registrada, el caracol ha crecido al tamaño normal y no muestra anomalías externas.

La anomalía pudo haber resultado de a) mutación, b) de un funcionamiento defectuoso de los odontoblastos que son responsables de la secreción de la rádula. La naturaleza altamente específica de la anomalía sugiere que pudo haber surgido como una mutación. La anomalía no mostro ningún retraso en el crecimiento del animal que lo poseía. Asimis- 
Anandakumar, S. and Ayyakkannu, K.- Radular anomaly in Hemifusus pugilinus

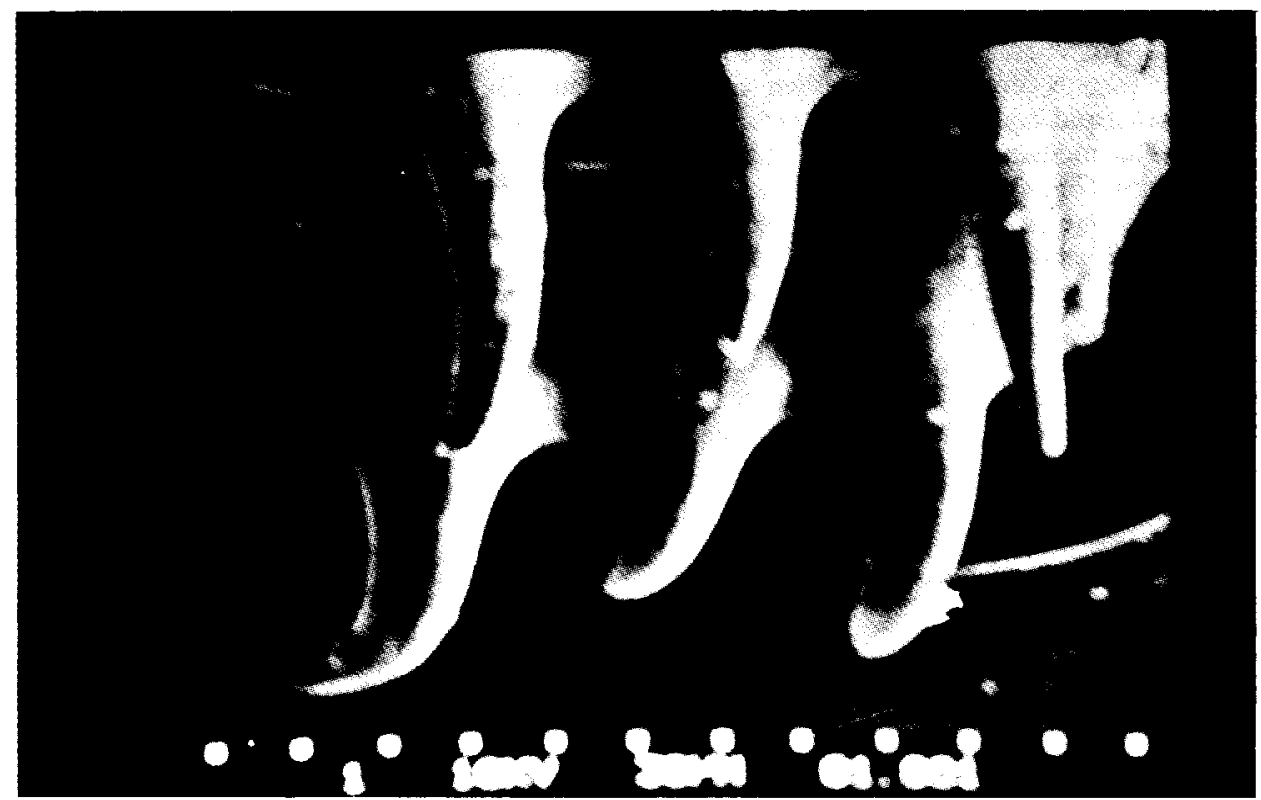

Figure 1. Rachidian tooth of $H$. pugilinus.

Figura 1. Diente raquídeo de $H$. pugilinus.

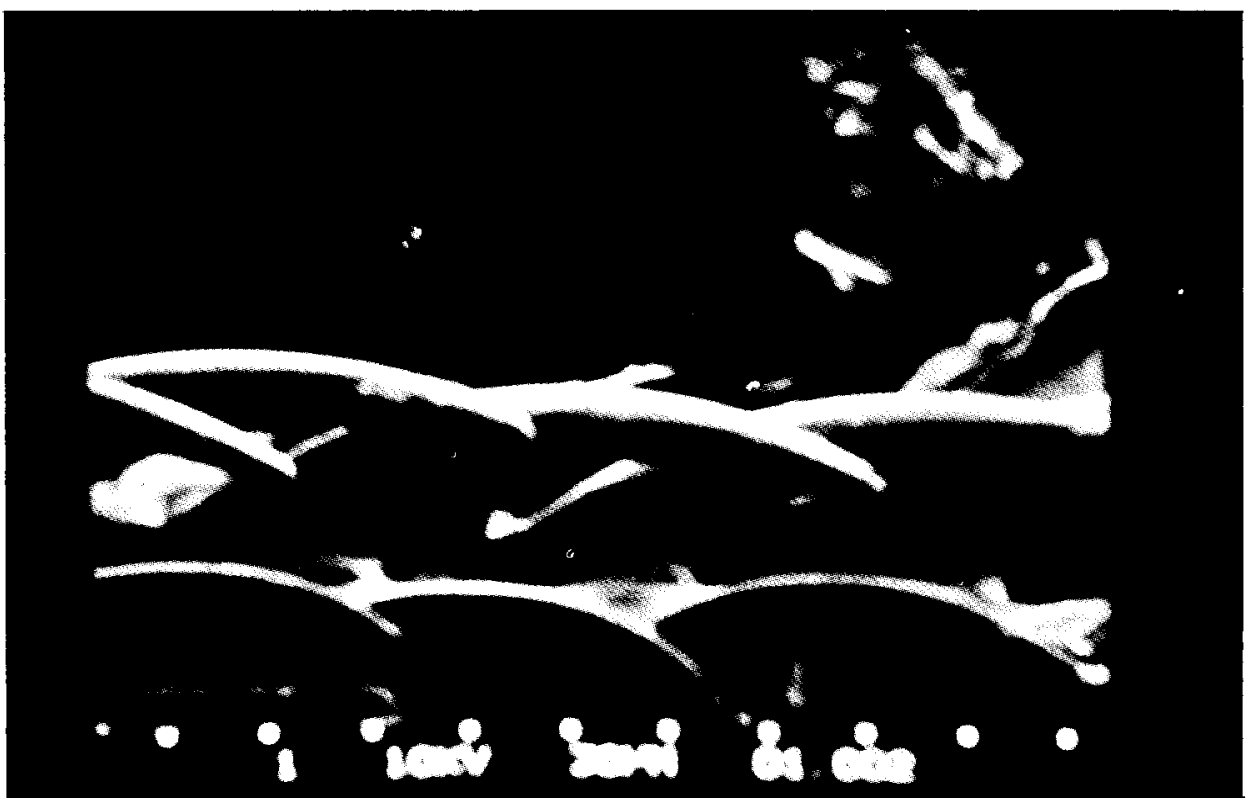

Figure 2. Lateral tooth of $H$. pugilinus.

Figura 2. Diente lateral de $H$. pugilinus. 


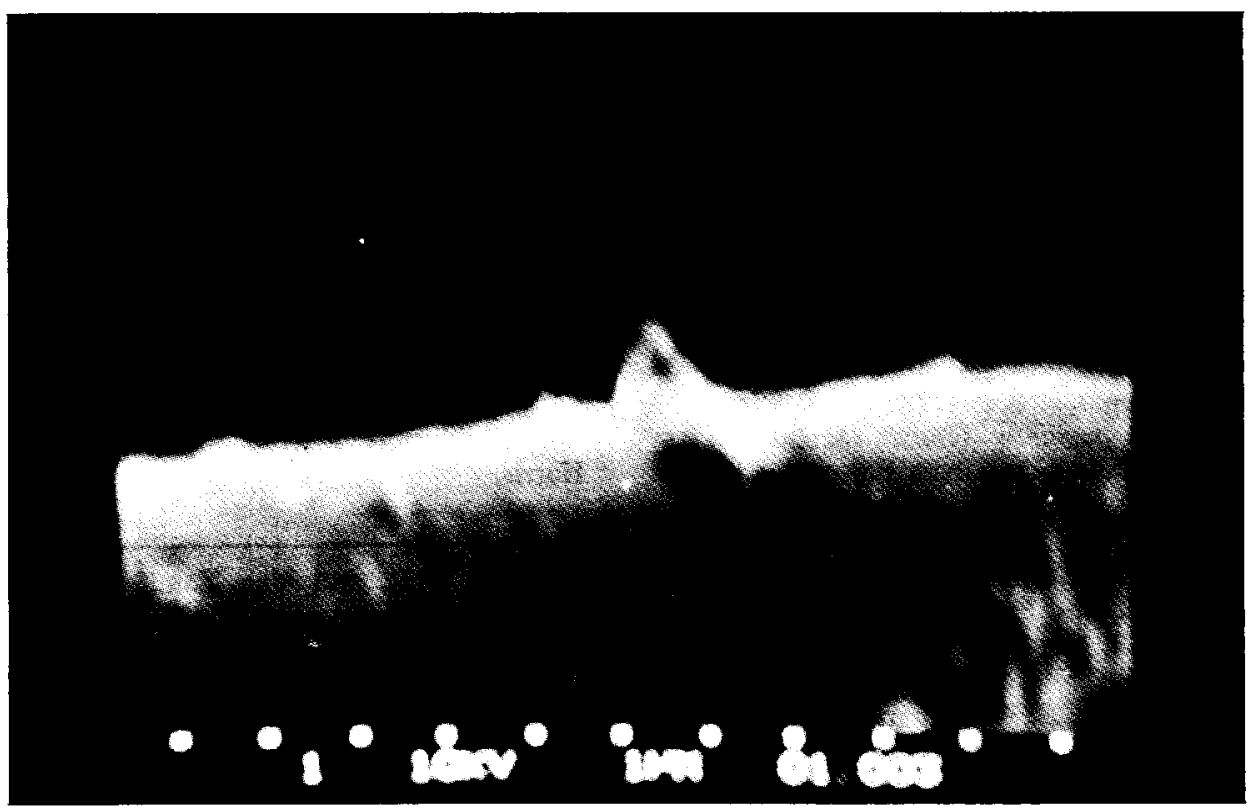

Figure 3. Anomalous spine on rachidian tooth of $H$. pugilinus.

Figura 3. Espina anómala en el diente raquideo de $H$. pugilinus.

The radulae are very specific in various families, genera and species of molluscs and they are used as an important factor in identification (Abbott, 1954). Even among species, individuals show a difference in the number of radular teeth (Fretter and Graham, 1962). In the present investigation the radula of $H$. pugilinus, except for the above mentioned anomaly, coincides with the features of typical rachiglossate type of radula. In the present study both males and females ranging from $51.50,96.40$ and $56.40-106.40 \mathrm{~mm}$ shell height were studied and it was inferred that the anomaly is not a sexual dimorphic feature as has been recorded in muricid Drupella sp. (Arakawa, 1957) and Nassa sp. (Maes, 1966), buccinid Pisaina sp. and archaeogastropod Hiloa sp. (Robertson, 1971). This anomaly occurred due to mutation as in Uraspinx sp., where the anomaly involving the total absence of central cusp in the rachidian tooth has been reported (Carriker, 1975). mo, el patrón de comportamiento en la alimentación del animal también confirmó este hecho. Por lo tanto, la anomalía podría ser ventajosa para su poseedor en la competencia para comida.

Las rádulas son muy específicas en varias familias, géneros y especies de moluscos y son utilizadas como factor importante en la identificación (Abbott, 1954). Aun entre especies, individuos muestran una diferencia en cl número de dientes radulares (Fretter y Graham, 1962). En esta investigación la rádula de $H$. pugilinus, excepto por la anomalia mencionada, coincide con caracteristicas de rádulas de tipo raquioglosa típicas. En el presente estudio, se estudiaron tanto machos qomo hembras de altura de concha de 51.50 , 96.40 y 56.40 - $106.40 \mathrm{~mm}$ y se infírió que la anomalía no es una característica de dimorfismo sexual como se ha registrado en el murícido Drupella sp. (Arakawa, 1957) y Nassa sp. (Maes, 1966), el bucínido Pisaina 
Anandakumar, S. and Ayyakkannu, K.- Radular anomaly in Hemifusus pugilinus

\section{ACKNOWLEDGEMENT}

The authors are greatly thankful to P. Santharoopan, Head R.S.I.C., I.I.T. Madras, for his help in scanning studies.

\section{LITERATURE CITED}

Abbott, R.T. (1954). American Sea Shells. Second edition, D. Van Nostrand Reinhold, N.Y., 541 pp.

Anandakumar, S. (1986). Studies on Hemifusus pugilinus (Born) (Mollusca Gastropoda; Volemidae) from Portonovo waters. M.Phil Thesis, Annamalai University, 117 pp.

Anandakumar, S., Amutharani, G., Chandra Leela, A.G. and Pragatheswaran, V. (1986a). J. Mar. Biol. Ass. India, 28 (1 \& 2): 35-40.

Anandakumar, S., Amutharani, G., Chandra Leela, A.G. and Antony Fernando (1986b). J. Mar. Biol. Ass. India, 28 (1 \& 2): 213-216.

Anandakumar, S., Amutharani, G., Chandra Leela, A.G. and Ayyakkannu, K. (1988). Indian J. Mar. Sci., 17: 240-241.

Arakawa, K.Y. (1957). Venus, 19: 19-57.

Carriker, M.R. (1975). The Veliger, 89. sp. y arqueogastrópodo Hiloa sp. (Robertson, 1971). Esta anomalía ocurrí debido a una mutación como en Uraspinx sp., donde se ha reportado la anomalía concerniendo la ausencia total de la cúspide central en el diente raquídeo (Carriker, 1975).

\section{AGRADECIMIENTO}

Los autores agradecen a P. Santharoopan, Jefe R.S.I.C., I.I.T. Madrás, por su ayuda en los estudios de barrido. Harris.

Traducido al español por Christine

Carriker, M.R. and Van Zandf, D. (1972). Trans Amer. Micros. Sec., 91: 45-66.

Fretter, V. and Graham, A. (1962). British Prosobranch Molluscs. Royal Society London, 755 pp.

Maes, V.O. (1966). The Nautilus, 79-81.

Robertson, R. (1971). Ann. Rep. Ame. Malacol. Union, 19-70.

Satyamurthy, S. (1960). The Bulletin of the Madras Goverment Museum, 1: 2-16. 